\title{
Assessment of Nephrotoxic Effect of Hypocotyl Methanolic Extract of Borassus Aethiopum in Wistar Rats
}

\author{
*Bello Sirajo Shittu', Oduola Taofeeq², Abdulhameed Aliu', Na'Allah Ibrahim², \\ Samuel Ajayi Ayooye ${ }^{3}$ Shagari Maryam Bala ${ }^{3}$. Mungadi Musa Sani ${ }^{2}$ \\ 'Department of Anatomy, Faculty of Basic Medical Sciences, College of Health sciences, Usmanu Danfodiyo University Sokoto. \\ 'Department of Chemical Pathology, School of Medical Laboratory Sciences, Usmanu Danfodiyo University Sokoto. \\ ${ }^{3}$ Department of Histopathology, Usmanu Danfodiyo University Teaching Hospital Sokoto.
}

\begin{abstract}
Background Borassus aethiopum is a tropical plant species belonging to the family Arecacea that grows widely across Africa. Different part of this plant has been applied for many purposes including Nutrition, Economic and Medicinal value. The Hypocotyl part of this plant has been widely used in traditional medicine practice. Few information is available about its safety; hence this study is aimed at assessing the effects of ingestion of methanolic hypocotyl extract of Borassus aethiopum on kidney function in Wistar rat.
\end{abstract}

Methodology: A sub chronic toxicity study was carried out with 20 Wistar rats, divided in to 4 groups of 5 rats each. Group 1 served as the control and was given distilled water only. Groups $(2,3$, and 4$)$ served as the study groups and were respectively administered with different doses of $500 \mathrm{mg} / \mathrm{kg}$, $1000 \mathrm{mg} / \mathrm{kg}$ and $1500 \mathrm{mg} / \mathrm{kg}$ of hypocotyl methanolic extract daily for 28 days. Renal function indices Urea, Creatinine, Sodium $\left(\mathrm{Na}^{+}\right)$, Potassium $\left(\mathrm{K}^{+}\right)$, Chloride $(\mathrm{Cl})$ and Bicarbonate $\left(\mathrm{HCO}_{3}{ }^{-}\right)$were assayed using standard techniques.

Results: No mortality was recorded in the rats after 24 hours and up to 14 days post oral administration. $\mathrm{LD}_{50}$ of the extract is thus greater than $5000 \mathrm{mg} / \mathrm{kg}$. In sub-chronic study, no gross treatment-related abnormalities were seen, as there were no significant difference between the values obtained for the control groups and intervention groups ( $p>0.05)$. Histology of the kidneys

Corresponding author:

Dr. BelloSS

Department of Anatomy

Faculty of Basic Medical Sciences

College of Health Sciences.

Usmanu Danfodiyo University Sokoto,

Nigeria.

EMail: sirajo.shiitu@udusok.edu.ng

GSM: +2348060176753 revealed some mild distortion of the kidney's architecture in the intervention groups.

Conclusion: The present study shows that methanolic extract of Borassus aethiopum hypocotyl is relatively not nephrotoxic in Wistar rats but is likely to produce damage in higher doses or prolong treatment.

Keywords: Nephrotoxic, Hypocotyl, Methanolic Extract, Borassus aethiopum, Wistar Rats

\section{Introduction}

Human uses of plant as herbs has been used in traditional medicine practices since prehistoric times. Plants synthesize hundreds phytochemical compounds with potential to treat some diseases in the biological system. However, a single plant contains more than one phytochemical, so effect of whole plant as medicine is uncertain (1).

Borassus aethiopum is a plant belonging to the family of Arecaceae, it grows widely across Africa. The roots, leaves, flower and fruits are used for multiple purposes such as nutritional and therapeutics, in treatment of fungal and viral infections (2), the antipyretic and antiasthmatic activities of this plant have also been reported (3). Study also revealed that the young germinating shoot (hypocotyl) of Borassus aethiopum extract has an anabolic effect on androgens, thus supporting its local use as an aphrodisiac (4). The hypocotyl part of the plant is popularly known as Muruchi or Gazari in Hausas it is harvested after 7 to 8 weeks of planting (5). It has been reported to enhance libido in women and aphrodisiac in 
men (6). The tremendous number of the therapeutics effects of Borassus aethiopum plants more especially the hypocotyl which is largely known traditionally and scientifically confirmed to have the ability to treat erectile dysfunction and to enhance sexual strength among other functions.

The kidneys are vital organs that perform a variety of important functions. The most prominent functions are removal of unwanted substances from plasma, homeostasis, electrolyte, and acid-base balance, as well as regulation and synthesis of hormones which include erythropoietin, renin, prostaglandins and calcitriol (7). Globally kidney disease represents $12^{\text {th }}$ cause of death and $17^{\text {th }}$ cause of disability, it has been estimated that about 5 million people died annually as a result of different kidney diseases (8). More than $80 \%$ of the population use medicinal plants as a primary source of health (9). However, available herbal products have no clear statement of content or medically related information on the package labels and have not been validated or certified by any recognized body (10). Despite the huge reliance and utilization of this plant (Borassus aethiopum) in many societies, there is less consideration about the potential toxicity of this plant to the body system. Moreover, the use of traditional herbs is believed to be among the predisposing factors towards the initiation and development of renal disease ranging from acute to chronic (8). Furthermore, nephrotoxic effect of Borassus aethiopum hypocotyl study has not been carried out in this region and there is little or no information about its safety on the kidney, therefore it become necessary to evaluate the effect of this plant on the kidney. The aim of this study was to evaluate the effect of ingestion of methanolic hypocotyl extract of Borassus aethiopum on kidney function in wistar rats.

\section{Materials and Methods}

Fresh leaves of Borassus aethiopum was collected from Dogon Daji area, Tambuwal LGA, Sokoto state, Nigeria. The plant was identified and authenticated at the Herbarium of Botany Unit, Department of Biological Sciences, Usmanu Danfodiyo University, Sokoto (UDUS). The plant was given herbarium voucher number UDUH/ANS/0334 and was deposited in the herbarium. Cold maceration method was employed for extraction. $1 \mathrm{~kg}$ of powdered form of the hypocotyl was soaked in to 5 litres of methanol for 3 days in a glass container with regular shaking of the mixture at interval.
On the $3^{\text {rd }}$ day, the solution was filtered using Whatman filter paper of size $150 \mathrm{~mm}$, the filtrate was then subjected to dryness in a hot air oven at $45^{\circ} \mathrm{C}$ to evaporate the solvent. The dried crude extract was stored at temperature of $4^{\circ} \mathrm{C}$ in a cleaned plastic container until use (11).

Apparently healthy male Wistar rats were used for the research. Ethical clearance was obtained from Faculty of pharmaceutical sciences, UDUS (PTAC/Be/HE/OT/1919). The animals were acclimatized for two weeks before the experiment. Animals were kept at temperature of $22^{\circ} \mathrm{C} \pm 3^{\circ} \mathrm{C}$ and 12 hours light and 12 hours dark, food and water were given ad libitum. Varying concentrations of crude extract were prepared on daily basis by diluting with water.

Sub-chronic toxicity study was carried out in accordance with OECD 407 guidelines (12). Twenty rats were divided in to four groups of five rats each. Group 1: control received distilled water. Groups 2, 3 and 4 received orally $500 \mathrm{mg} / \mathrm{kg}, 1000 \mathrm{mg} / \mathrm{kg}$ and $1500 \mathrm{mg} / \mathrm{kg}$ body weight respectively daily for 28 days and were observed daily for general symptoms of toxicity and mortality. The rats were fasted overnight on day 28 and sacrificed the next day. Five (5) $\mathrm{ml}$ of blood was collected through cardiac puncture, the blood was centrifuged at $4000 \mathrm{rpm}$ for 5 minutes, and the plasma was collected and kept at $-20^{\circ} \mathrm{C}$ until used for analysis. Urea (13), Creatinine (14), Sodium (7), Potassium (7), Chloride (14) and Bicarbonate (7) were all analyzed using the serum.

The kidneys were harvested and fixed with $10 \%$ formalin and processed using automatic tissue processor. Tissue was section at $4 \mu \mathrm{m}$ thickness and stained with haematoxylin and Eosin, the slides were viewed under light microscope.

The data were analysed using the statistical package for social sciences (SPSS) version 20.0 The data were expressed as the mean \pm standard error of mean (SEM). One-way analysis of variance (ANOVA) was used for comparison between groups. P-value of less than 0.05 $(p<0.05)$ was considered to be statistically significant.

\section{Results}

Table 1 shows the p-value obtained by comparing control group against the groups administered with the extract in sub-chronic toxicity study. There was no significant difference in the renal indices estimated when the treated groups were compared against the control groups 
$(\mathrm{p}>0.05)$.

Table 1 Comparison between the treatment groups and control group in the study

\begin{tabular}{llll}
\hline Parameters & $\begin{array}{l}\text { P-value } \\
\text { Group 1 Vs } \\
\text { Group 2 }\end{array}$ & $\begin{array}{l}\text { P-value } \\
\text { Group 1 Vs } \\
\text { Group 3 }\end{array}$ & $\begin{array}{l}\text { P-value } \\
\text { Group 1 Vs } \\
\text { Group 4 }\end{array}$ \\
\hline Urea $(\mathrm{mMol} / \mathrm{L})$ & 0.97 & 0.80 & 0.44 \\
$\mathrm{Cr}(\mu \mathrm{Mol} / \mathrm{L})$ & 0.49 & 0.93 & 0.49 \\
$\mathrm{Na}(\mathrm{mMol} / \mathrm{L})$ & 0.93 & 0.98 & 0.11 \\
$\mathrm{~K}(\mathrm{mMol} / \mathrm{L})$ & 0.30 & 0.99 & 0.61 \\
$\mathrm{Cl}(\mathrm{mMol} / \mathrm{L})$ & 0.36 & 0.61 & 0.12 \\
$\mathrm{HCO}_{3}(\mathrm{mMol} / \mathrm{L})$ & 0.92 & 0.99 & 0.99 \\
\hline
\end{tabular}

$\mathrm{Cr}=$ Creatinine $\mathrm{Na}=$ Sodium $\mathrm{K}=$ Potassium $\mathrm{Cl}=$ chloride $\mathrm{HCO}_{3}=$ Bicarbonate, $\mathrm{P}<0.05$

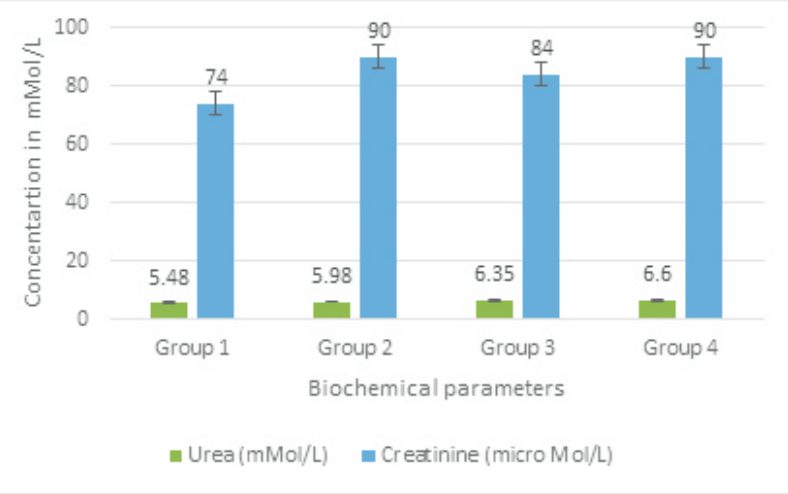

Figure 1: Effect of Borassus aethiopum hypocotyl methanolic extract on urea and creatinine after subchronic administration.

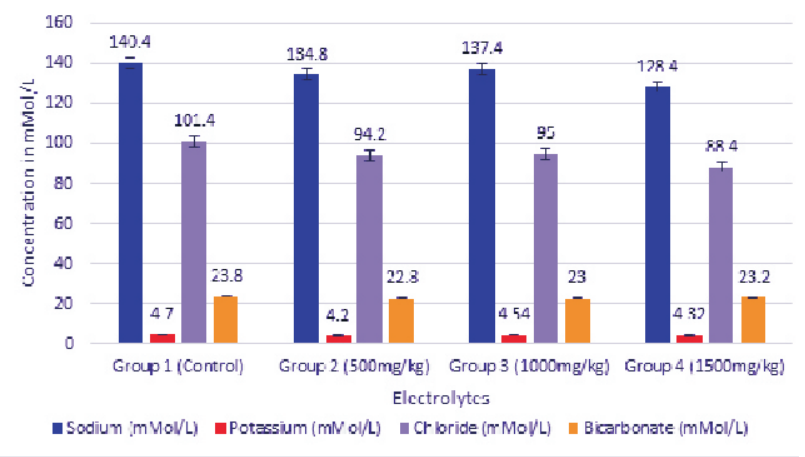

Figure 2: Effect of Borassus aethiopum hypocotyl methanolic extract on Electrolytes after sub-chronic administration.
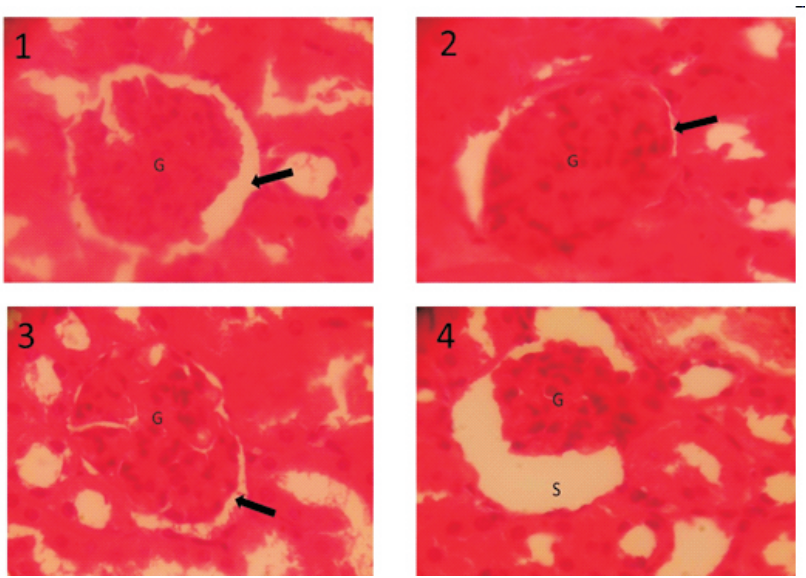

Figure 3: Effect of Borassus aethiopum hypocotyl methanolic extract on Histological appearance of glomerulus and glomerular space after sub-chronic administration. H\&E Stain was used at X40

1: Normal glomerulus and capsular space.

2: Mild reduction in capsular space

3: Mild reduction in capsular space.

4: Glomerular shrinkage with wide capsular space.

G: Glomerulus Arrow and S: Capsular space

\section{Discussion}

This study reports the findings of research into the assessment of nephrotoxic effect of Borassus aethiopum hypocotyl methanolic extract in Wistar rats. In the clinical laboratory, kidney function tests were used in the assessment of renal disease, water balance, and acid base disorders (7). The Urea, Creatinine and Electrolytes (Sodium, potassium, chloride and bicarbonate) are markers of kidney function.

In this research work, there was no statistically significant difference $(\mathrm{P}>0.05)$ in the serum urea levels of the rats administered with Borassus aethiopum hypocotyl methanolic extract in oral sub-chronic toxicity study when compared with their control group counterpart. However, the values obtained shows a slight increase among the groups; from group 1 to group 4 values increases with increase in dose, but they are all within the normal range.

There was no statistically significant difference $(\mathrm{P}>0.05)$ in the Creatinine levels of the rats' groups administered with the extract when compared to their control group counterpart. However, like urea the creatinine levels of the rats administered with the extract shows an apparent 
Assessment of Nephrotoxic Effect of Hypocotyl Methanolic Extract of Borassus Aethiopum in Wistar Rats

increased of serum creatinine level when compared to their control group counterpart. But in contrast to urea, the values obtained for creatinine showed some little fluctuation from one group to another. Group 2 (500 $\mathrm{mg} / \mathrm{kg}$ body weight) and group $4(1500 \mathrm{mg} / \mathrm{kg}$ body weight) showed identical values whereas the intermediate group 3 (1000mg/kg body weight) reflect a value lower than the former. Thus, variations in the creatinine levels among the groups that received the extract does not indicate dose dependent variations. However, the increase in urea and creatinine levels agrees with findings of Muhammad (21). that, 25\%, 50\% and $75 \%$ of pulverized Borassus aethiopum shoot diet (Borassus aethiopum shoot powder + Normal feed) showed a dose dependent increase in serum urea and creatinine levels of albino rats except that, the values for creatinine levels found in this study showed some little fluctuation among the groups.

In this research work, there was no statistically significant difference $(\mathrm{P}>0.05)$ in the serum electrolyte (sodium, potassium, chloride and bicarbonate) levels of rats administered with methanolic extract of Borassus aethiopum shoot (hypocotyl) in sub chronic toxicity study when compared with their control group counterpart.

Normal plasma level of Urea, Creatinine and Electrolytes (sodium, potassium, chloride and bicarbonate) in both acute and sub chronic toxicity studies is an indicator of normal kidney function and this implies that methanolic hypocotyl extract of Borassus aethiopum is relatively not nephrotoxic. However, the increased level of urea and creatinine in rats administered with the extract may indicate potential nephrotoxic effect at higher doses and/or long-term usage. This agrees with the findings of Umar (22) that, elevated level of creatinine indicate kidney malfunction perhaps due to the phytochemical detected in the sample such as tannins, cardiac glycosides, saponin and flavonoids. This is also in agreement with the findings of Muhammad (21) that, ingestion of Borassus aethiopum shoot prepared diet for albino rats indicate a significant dose dependent increase in the serum level of urea and creatinine. Moreover, 70\% ethanolic extract of Borassus aethiopum seeds was reported to cause a dose dependent anti-inflammatory effects in carrageenan-induced foot oedema, which was thought to inhibit the release of prostaglandin (3), inhibition of prostaglandin may affect the auto regulatory mechanisms of the glomerular fenestration to dilate and constrict according to substance size, which can result in the accumulation of substance in the blood.

The histology of kidney in the control group showed normal kidney architecture, Group 2 showed mild inflammation of the glomeruli with a masked capsular space, Group 3 section showed heavy proliferation of glomeruli manifested with highly compressed capsular space but no sclerosis. Group 4 showed a very wide capsular space with small sized glomerular membranes which indicate severe glomerular shrinkage. The different lesions observed in the kidney sections of the rats administered with the extract indicate a mild renal damage perhaps due to the constituents of the plant extract such as tannins which has astringent property and saponins which may contribute to induction of apoptosis and necrosis. However, the lesions from the kidney may not be evident by blood urea and Creatinine levels, because these parameters are late markers of kidney failure (7).

\section{Conclusion}

In this study, there was no gross evidence from the estimated renal indices that indicate toxicity of Borassus aethiopum hypocotyl methanolic extract. Moreover, the histopathological study of the experimental animal revealed some pathological changes in the kidney sections of the animals administered with the extract. Thus, we concluded that methanolic extract of Borassus aethiopum hypocotyl is relatively nephrotoxic in Wistar rats but not likely to cause biochemical changes in the kidney function.

\section{References}

1. Ahn, K. (2017). The worldwide trend of using botanical drugs and strategies for developing global drugs. BMB reports, 50(3): 111-116.

2. Sakande, J., Nacoulma, O. G., Nikiema, J. B., Lompo M., and Bassene, E. (2014). Study of antipyretic effect of Borassus aethiopum male inflorescence extract Med.d Afrique Noire; 51: 280-282.

3 Sarkodie J. A., Sylvia S. A., Irene K. A., Bekoe, E. O., Charles, D. Y., Kurukulasuriya, A. M., Emanuella, A., Dominic E. A., Isaac, A. K., Maxwell, S., Vida, L.K., Seigfried A. O., John, D. L., Philip, D., Benoit N. B., and Alexander N. K. (2015). Borassus aethiopum, A potential medicinal source of antioxidants, anti-inflammatory and antimicrobial agents. Medical Publication Journal; 1(1): 3

4 Akinniyi, J. A, Waziri, M. and Usman, H. S. (2010). Assessment of the Anabolic Effect of Androgens of the Edible Portion of the Shoot of Giginya Plant (Borassus aethiopum mart). Journal of Science Research; 2(2): 362-368.

5 Ahmed, A., Djibrilla, A., Clerge, T., and Clement (2010). Physicochemical properties of Palmyra palm (Borassus aethiopum Mart) fruits 
Assessment of Nephrotoxic Effect of Hypocotyl Methanolic Extract of Borassus Aethiopum in Wistar Rats

from northern Cameron. African Journal of Food Science; 4: 115-119.

6 Akinniyi, J. A. and Waziri, M. (2011). Proximate value and Mineral content of the shoot of Borassus aethiopum mart (Giginya). Journal of Chemical Society of Nigeria; 10(4): 100-103.

7 Bishop, M. L., Fody, E. P. and Schoeff, L. E. (2013). Clinical chemistry, principle, techniques and correlation. $7^{\text {th }}$ edition, Wolter Kluwer: Lippincott William and Wilkins. 349-358, 573pp.

8 World health organisation (WHO) (2011). The world traditional medicine situation, in traditional medicines: Global situation issues and challenges. Geneva 3: 1-14.

9 Visweswari, G., Christopher, R., and Rajendra, W. (2013). Phytochemical screening of active secondary metabolites presents in Withanias omnifera root, role in traditional medicine. International Journal of Pharmaceutical Science and Research; 4(7): 2770-2776.

10 Asif, M. (2012). A brief study of toxic effects of some medicinal herbs on kidney. Advance Biomedical Research; 1: 44.

11 Ahmed, Risikat N., and Sani A. (2013). Antimycotic activity and toxicological effects of stem bark extract of Vitellaria paradoxa in wistar rats. Science international (Lahore), 25(1): 91102

12 O.E.C.D. (2008). Toxicity test in: organization for economic cooperation and development guidelines for testing chemicals, No 425. Paris, France.

13 Monica, C. (2009). District laboratory practice in tropical countries; $2^{\text {nd }}$ edition. Cambridge University press. 337-340pp.

14 Burtins, C. S., Ashwood, E. and Bruns, D. E. (2012). Teizt text book of clinical chemistry and molecular diagnostics. Saudar Elsevier, 7967, 984-990 pp.

15 Ochei, J. and Kolhaktar, A. (2007). Medical Laboratory Science Theory and Practice, $6^{\text {th }}$ edition. Tata Mc Gracwc Hill publishing company limited, $113 \mathrm{pp}$.

16 Gounden, V. and Jialal I. (2019). Renal function tests. In: statpearls [updated 2019 Apr 3]. In: statpearls [Interenet]. Treasure Island (FL): Statpearls publishing.

21 Muhammad, S., Umar, K. J., and Hassan, S. W. (2019). Toxicity studies of African palmyrah palm (Borassus aethiopum) shoots. African Journal of Pure and Applied Chemistry; 13(2): 27-33.

22 Umar, K. J., Bello, M., Abdullahi, B., Muhammad, S., Lawal, G. H., Nasiru, A. S., (2015). Nutritional and anti-nutritional profile of Borassus aethiopum (African palmyrah palm) shoots. International Journal of Sciences, Basic and Applied Research; 24(3): 39-49. 